УДК 343.231

DOI https://doi.org/10.32837/pyuv.v1i4(29).405

\author{
I. I. Давидович \\ orcid.org/0000-0003-4135-9848 \\ кандидат юридичних наук, доцент, \\ доцент кафедри крилінального права та крилінологї \\ Київського національного університету ілені Тараса Шевченка \\ К.П.Задоя \\ orcid.org/0000-0003-2362-7116 \\ кандидат юридичних наук, доцент, \\ доиент кафедри кримінального права та кримінології \\ Київського національного університету імені Тараса Шевченка
}

\title{
ЦІННІСНА КОНЦЕПЦІЯ ОБ'ЄКТА ЗЛОЧИНУ В ДОКТРИНІ КРИМІНАЛЬНОГО ПРАВА УКРАЇНИ: ПРОБЛЕМИ ФІЛОСОФСЬКОГО ПІДІРУНТЯ
}

Ціннісна концепція об’єкта злочину, що сформувалася в українській кримінально-правовій доктрині упродовж 1990 -х років, є, напевне, однією $з$ найбільш вагомих альтернатив концепції «об’єкт злочину - суспільні відносини», яка мала домінуючий характер у радянський період і й досі має серйозну підтримку. Головним «ідеологом» ціннісної концепції можна вважати Є.В. Фесенка, який сформулював положення цієї концепції в численних роботах $[1 ; 2$, с. $123-133 ; 3 ; 4]$. Окрім того, свою прихильність цій концепції свого часу засвідчило чимало українських криміналістів, наприклад, П.С. Матишевський і П.П. Андрушко [5, с. $96-101 ; 6 ; 7$, с. $47-48]$.

Ціннісна теорія об'єкта злочину є однією 3 численних спроб пострадянських криміналістів запропонувати аргументовану альтернативу концепції "об'єкт злочину - суспільні відносини». Як наслідок, у фундамент ціннісної концепції завідомо закладене протиставлення цінностей і суспільних відносин. На це вказує, наприклад, уже сама структура роботи Є.В. Фесенка «Злочини проти здоров'я та системи заходів з його охорони : монографія». Розділ, присвячений об'єкту злочину, починається з аналізу (критики) концепції «об'єкт злочину - суспільні відносини», а продовжується викладенням положень ціннісної теорії об'єкта злочину. Однак чи справді дві згадані концепції об’єкта злочину є настільки відмінними та несумісними, як стверджується в літературі?

Найперше варто виокремити ключові (фундаментальні) положення ціннісної концепції об’єКта злочину:

1. «Об”єкт злочину можна визначити як цінності, що охороняються кримінальним законом, проти яких спрямоване злочинне діяння та яким воно може заподіяти або спричиняє шкоду».

2. «Цінності - це різноманітні об’єкти матеріального світу, зокрема й сама людина, які мають суттєве позитивне значення для окремих осіб, соціальних груп і суспільства загалом» .
3. «До елементів цінностей як об'єкта злочинів варто зарахувати п'ять класів елементів: потерпілих, їхні інтереси та права; соціальні зв'язки, предмети (матеріалізовані блага); нематеріалізовані блага, які належать потерпілим» .

4. В основі ціннісної концепції об'єкта злочину перебувають положення діалектичного матеріалізму [4, с. 50-52].

У сучасній кримінально-правовій літературі ці постулати ціннісної концепції вже неодноразово зазнавали критики. Авторами цих зауважень були як ті представники доктрини, що підтримують концепцію "об'єкт злочину - суспільні відносини» (наприклад, М.Й. Коржанський, В.М. Білоконєв) $[8$, с. $8-9,23 ; 9$, с. $16-17]$, так і ті, хто обстоює власні, оригінальні концепції об'єкта злочину (наприклад, С.Я. Лихова, С.Б. Гавриш) [10, с. 33-43; 11, с. 60-61]. Окрім загальних тверджень про «абстрактність», «некоректність», «неточність», «еклектичність» ціннісної концепції об'єкта злочину висловлено й низку конкретних контраргументів:

1) цінності набувають соціального значення лише в контексті суспільних відносин (М.Й. Коржанський, В.М. Білоконєв);

2) співвідношення понять «цінність» $\mathrm{i}$ «благо» як роду та виду невиправдане, оскільки з філологічного погляду ці поняття - синоніми (С.Б. Гавриш);

3) категорія «цінності» має мінливий і неуніверсальний характер (С.Я. Лихова);

4) співвідношення між структурними елементами в межах ціннісної концепції є нечіткими та спірними (С.Б. Гавриш, С.Я. Лихова).

На нашу думку, критика ціннісної концепції об'єкта злочину закономірно спрямована на виявлення ï «слабких місць» $\mathrm{i}$, звичайно, послаблює наукову значимість згаданої концепції. Однак при цьому, як видається, оминаються увагою фундаментальні засади ціннісної концепції.

Ціннісна концепція об’єкта злочину, за твердженням Є.В. Фесенка, має певне філософське 
підгрунтя у вигляді вчення про цінності, розробленого в рамках діалектичного матеріалізму. Це, однак, на наш погляд, не отримало належної уваги з боку критиків ціннісної концепції об'єкта злочину. На нашу думку, концепція потребує ретельного аналізу саме з погляду положень філософського вчення про цінності.

Цінності стають предметом серйозної уваги філософської науки із середини 60-х років XIX ст. Зокрема, важливу роль для цього процесу відіграв трактат німецького філософа Г. Лотце «Основи практичної філософії», який являє собою спробу концентровано опонувати ідеї про однорідність реальності, що сформувалася в епоху Просвітництва [12, с. 14 ; 13 , с. $260 ; 14$, с. $128 ; 15$, с. 5]. Зазначений науковий трактат став каталізатором інтересу філософської науки до проблеми цінностей. Відтоді вони все частіше опиняються у фокусі філософських досліджень. Однак підсумком цих досліджень не стало створення єдиної більш-менш усталеної теорії цінностей. Існує від трьох до дванадцяти напрямів (течій) в аксіології [12, с. 23-24].

Не маючи на меті характеризувати всю множину напрямів аксіології, виокремимо основні з них: натуралістичний напрям, суб'єктивний ідеалізм, феноменологічна теорія цінностей, аксіологічний трансценденталізм, теорія цінностей у рамках діалектичного матеріалізму (марксистська теорія цінностей).

Натуралістичний напрям трактує цінності як природні властивості, зокрема як властивості задовольняти різноманітні біопсихологічні потреби людей. До цього напряму можна зарахувати евдемоністичні та гедоністичні концепції в британській етиці XIX ст., моральний прагматизм А. Фульє, а також цілу низку аксіологічних теорій в американській філософії - теорію У. Томаса та Ф. Знанецького, теорію інтересу Р.Б. Перрі [16, с. $26 ; 17$, с. $114 ; 18$, с. 154-170]. Зокрема, У. Томас та Ф. Знанецький визначають цінності як «будь-який предмет, наділений таким, що піддається визначенню, змістом і значенням для будь-якої соціальної групи» [17, с. 114]. Р.Б. Перрі вважав, що цінності - це те, що задовольняє інтереси людини [18, с. 158]. На початку XX ст. вона була піддана серйозній критиці англійським філософом Д.Е. Муром, який відзначив, що цінність є «позаприродна» якість, її не можна вивести з усього того, що ми знаємо про закони буття. Д.Е. Мур дав визначення, характерне для представників цього напряму. Вони, як правило, стверджують, що цінності - це щось, що має певне значення, задовольняє певні потреби, а така здатність (якість) - це «щось» має, оскільки воно є цінністю. Після критики Д.Е. Мура аксіологічний натуралізм утратив свою наукову вагу та поступався місцем іншим філософським концепціям [16, с. $27-28 ; 18$, с. 154$]$.
Суб’єктивний ідеалізл відіграє вирішальну роль у межах ціннісної теорії суб'єкта. Окремі представники цього напряму розглядають цінності як психічні явища у свідомості людини - «почуття цінності» (А. Мейнонг) [19, с. 1-2], 22факти почуття, бажання, задоволення, рішення» (Д. Паркер) [20, с. 35]. Інші розглядають цінність як психічне ставлення людини до об'єкта оцінки (І. Гайде, Дж. Елліс, Р. Фрондіцці) [12, с. 50; 15 , с. $39 ; 19$, с. 11$]$.

Феноленологічна теорія иінностей виходила з реальності, об’єктивності цінностей. Однак ця об’єктивність є специфічною. Так, засновник феноменологічного напряму в аксіології М. Шелєр стверджував, що цінності - це особливі якості, які не можна вивести з ознак чи якостей, які самі не є цінностями. Він розрізняв носіїв якостей, що можуть бути пізнані за допомогою теоретичних функцій інтелекту - речі, і носіїв ціннісних якостей - блага. На думку М. Шелєра, цінності можуть бути пізнані за допомогою особливого способу пізнання - феноменологічної інтуїції $[19$, с. 5-6].

Погляди М. Шелєра надалі систематизовано та розвинуто М. Гартманом. Він уважав цінності ідеальними й водночас змістовно-матеріальними, об'єктивними утвореннями. Така теза цілком узгоджується з поглядами М. Гартмана на реальний світ, у якому він виділяв чотири шари (матерія, життя, психічні та духовні явища). На його думку, ідеальний світ, проявом якого є цінності, існує незалежно від свідомості, яка спрямована на ідеальне буття як на свій предмет, як на об'єктивне «в собі буття» $[19$, с. 6-7].

Аксіологічний трансиенденталізл розроблений і сформульований представниками Баденської (Південно-західної) школи неокантіанства В. Віндельбандом і Г. Ріккертом і близьким до них філософом Т. Мюнстербергом. Ключова теза цього напряму аксіології полягала в чіткому розрізненні сфери дійсності (буття) та сфери цінностей. На думку Г. Ріккерта, цінності не стосуються ані царини об’єкта, ані царини суб'єкта, а утворюють абсолютно самостійну царину, що лежить по той бік суб’єкта й об’єкта (трансцендентна царина). Емпіричні носії цінностей неокантіанці називали благами [13, с. 259-269; 20, с. 33-35].

Теорія иінностей у ралках діалектичного матеріалізлу (ларксистська теорія иінностей). Цей напрям аксіології становить особливий інтерес у світлі предмета розвідки, адже, за твердженням прихильників ціннісної концепції об’єкта злочину, остання спирається саме на уявлення про цінності, що сформувалося в рамках діалектичного матеріалізму. Формування цього напряму аксіології варто, очевидно, пов'язувати з науковою дискусією, яка відбувалася упродовж 1960-х років у середовищі радянських філософів щодо 
доцільності виокремлення в межах марксистської філософії такого напряму, як аксіологія. Результатом дискусії стала поява марксистська теорія цінностей.

Щоб отримати досить повне та водночас лаконічне уявлення про їі сутність, звернемося безпосередньо до понятійного апарату цієї теорії. Наведемо два визначення поняття «цінності», розроблені представниками марксистської теорії цінностей.

Отже, перше 3 них запропоноване одним із фундаторів марксистської аксіології В.П. Тугаріновим: «Цінностями є предмети, явища та їх властивості, котрі потрібні (необхідні, корисні, приємні тощо) людям певного суспільства або класу й окремій особистості, як засоби задоволення їхніх потреб та інтересів, а також ідеї та переконання як норми, цілі й ідеали» [21, с. 11].

Інакше визначав поняття «цінності» науковий опонент В.П. Тугарінова О.Г. Дробницький: «Цінності - це форма прояву певного роду відношення між суб'єктом та об'єктом» [22, с. 33].

Тепер порівняємо ці визначення 3 класичним для ціннісної концепції об'єкта злочину розумінням цінності, яке свого часу запропоноване Є.В. Фесенком і наведене нами вище. Вочевидь, воно є дуже близьким до визначення В.П. Тугарінова (на роботу якого в монографії Є.В. Фесенка єпосилання, щоправда, з приводу іншоїпроблеми). Заради справедливості варто визнати, що між визначеннями цінностей Є.В. Фесенка та В.П. Тугарінова існують і певні серйозні розбіжності. В.П. Тугарінов розуміє під цінностям, зокрема, властивості явищ і предметів. Є.В. Фесенко, у свою чергу, визначає цінності як об'єкти матеріального світу, хоча водночас стверджує, що цінності можуть існувати в матеріалізованій і нематеріалізованій (права, інтереси) формах. Однак, попри ці відмінності, логічна структура обох визначень є подібною: «Цінності - це те, що має певне значення для когось». Хоча цей факт начебто вказує на існування очевидного зв'язку між марксистською теорією цінностей і ціннісною концепцією об’єкта злочину, однак під час більш детального аналізу згаданий зв'язок не виглядає таким однозначним.

По-перше, визначення (і загалом уся концепція цінностей) В.П. Тугарінова серйозно критикувалося іншими радянськими філософами. Зокрема, В.О. Василенко вказував на те, що в межах формулювання В.П. Тугарінова цінність ототожнюється з її носієм [20, с. 19]. О.Г. Дробницький звинувачував В.П. Тугарінова, який поділяв цінності на соціальні та природні, у приписуванні цінностям природного характеру, а отже, у прояві аксіологічного натуралізму [22, с. 296-299].

По-друге, і радянські, і сучасні філософи надзвичайно гостро критикують спроби звести розуміння цінностей до їх матеріальних носіїв.
«Цінності не існують як певні об’єктивні предмети» [23, с. 221]. «Цінність не варто ототожнювати $з$ предметом, тобто з тим чи іншим предметом, явищем, подією, вчинком, які є носієм цінності» [20, с. 23]. «Філософське осягнення цінностей починається з розрізнення, принципового розмежування цінностей і «благ», у яких вони втілюються. У звичайному повсякденному слововживанні цінності, навпаки, сплутуються з їх уречевленими носіями, тобто властивостями, котрими речі зобов’ язані людському ставленню до них ( «практичному» в широкому сенсі, включаючи етичний), і помилково приписуються їм самим... У силу такого сплутування цінностей і благ, від якого не вільні емпіричні науки, в тому числі й соціологія, виникає небезпека релятивізму в теорії цінностей» [13, с. 261]. «Цінностями не можуть бути певні предмети, явища, процеси поза певним (ціннісним) відношенням до них людини, суспільства» [24, с. 59]. «Цінність не можна ототожнювати 3 об'єктом цінності, оскільки вона не є іманентною об'єкту, непритаманна йому природно-історично» [25, с. 11]. Отже, визначення цінностей В.П. Тугарінова (а разом із ним і Є.В. Фесенка) фактично є проявом такого розуміння цінностей, яке традиційно й обгрунтовано критикувалося в рамках марксистської теорії цінностей.

По-третє, для марксистської теорії цінностей домінуючим стало запропоноване О.Г. Дробницьким уявлення про цінності як про особливе об'єкт-суб'єктне відношення. Подібного підходу дотримувалися, наприклад, I.С. Нарський [23, с. 220-225], В.О. Василенко [20, с. 13-23], Л.М. Столович [15, с. 38-40], М.С. Каган [12, с. 48-54]. Необхідно звернути увагу на те, що представники марксистської аксіології намагалися провести межу між власними уявленнями про цінності й уявленнями про цінності представників суб’єктивного ідеалізму, які розглядали цінність як психічне ставлення суб'єкта до предмета оцінювання. Представники діалектичного матеріалізму стверджували, що вони розуміють під цінністю не просто гносеологічне відношення між суб'єктом та об'єктом, а відношення предметно-практичне [15, с. 38-47]. У зв'язку з цим О.Г. Дробницький послідовно розвивав у роботах тезу, що об'єктом оцінювання $€$ «суспільний предмет»: «Це кристал, у котрому, як у фокусі, відображаються суспільні відносини, це вузлова точка соціальних зв' язків і залежностей, предмет, що виступає у своїх різних напрямах і призначеннях... Зовсім не обов'язково розуміти під ним те, що в природному стосунку являє собою річ або процес, зовнішні стосовно людини. Таким предметом може бути й сама людина як індивід, відмінний від усіх інших, або навіть суспільний клас... У площині різних суспільних відносин предмет повертається до суб'єкта своїми різними сторонами, здатний виконувати різні 
ролі та задовольняти різні потреби» [22, с. 38-40]. Отже, визначення поняття «цінності», запропоноване О.Г. Дробницьким, є одним із найважливіших постулатів марксистської теорії цінностей.

Три наведені вище зауваження дають змогу ствердити, що концепція цінностей В.П. Тугарінова, а отже, і ціннісна концепція об'єкта злочину Є.В. Фесенка не відповідають загальноприйнятим положенням учення про цінності, яке сформувалося в річищі діалектичного матеріалізму.

Очевидно також, що ціннісна концепція об'єкта злочину має певну спорідненість із натуралістичним напрямом аксіології, що, як уже відзначалося вище, є ледве не рудиментом у філософських пошуках 3 приводу сутності й природи цінностей. Існує, однак, один важливий аспект, який ставить таку спорідненість під сумнів. Ціннісна концепція Є.В. Фесенка виходить із того, що цінності це об'єкти, які мають суттєве позитивне значення для окремих осіб, соціальних груп і суспільства загалом. Однак значна група представників натуралістичної аксіології взагалі відкидала можливість існування соціальних цінностей і пов'язувала існування цінностей виключно з біопсихологічними потребами людини [18, с. 162].

Ураховуючи все вищевикладене, можна зробити три проміжні висновки.

По-перше, ціннісна концепція об’єкта злочину має вкрай слабкий зв' язок (якщо взагалі має його) iз загальноприйнятими положеннями марксистської теорії цінностей.

По-друге, ціннісна концепція об'єкта злочину не має чіткого зв'язку з будь-якою іншою фундаментально розробленою філософською теорією цінностей.

По-третє, ціннісна концепція об’єкта злочину є проявом філософського редукціонізму, тобто спрощеного підходу до розуміння сутності цінностей.

Нагадаємо, що на початку дослідження ми ставили мали меті з'ясувати, чи справді ціннісна концепція об’єкта злочину якісно відмінна від концепції «об’єкт злочину - суспільні відносини». Якщо відштовхуватися від загальноприйнятого для діалектичного матеріалізму розуміння цінностей як особливого об'єкт-суб'єктного відношення, питання про співвідношення цінностей і суспільних відносин є абсолютно закономірним. О.Г. Дробницький зазначав із цього приводу: «Не предмет сам по собі володіє цінністю, а людина робить його об’єктом своєї потреби в процесі практичної діяльності. Ми маємо місце не з властивістю, а із суспільним відношенням» [22, с. 38]. Подібна точка зору підтримувалася й радянською соціологією: «У всіх цих випадках перед нами цілком об’єктивні критерії ціннісних відношень: у їх основі лежать суспільні відносини людей, уречевлені в соціальних інститутах» [26, с. 61].
Суспільні відносин, у свою чергу, можуть бути визначені як категорія, що виражає спосіб сукупного взаємозалежного буття певних груп людей, сутність якого (цього способу) зводиться до наявності для них реальної можливості вступити з необхідністю в актуальний взаємозв'язок через діяльність і її продукти [27, с. 393]. Отже, соціальні (суспільні) цінності можуть бути інтерпретовані як особливого роду суб'єкт-об'єктні відносини в межах суспільних відносин, які полягають у ставленні учасників суспільних відносин до інших компонентів суспільних відносин. Тобто існування суспільних відносин є передумовою існування соціальних (суспільних) цінностей, а отже, жодних глобальних протиріч (жодної опозиції) між цими явищами не існує. 3 огляду на це, видаються виправданими твердження тих представників доктрини кримінального права, які вважають, що соціальні (суспільні) цінності охоплюються поняттям «суспільні відносини» [28, с. 40-43].

Отже, намагання побудувати ціннісну концепцію об’єкта злочину як таку, що водночас спирається на засади діалектичного матеріалізму та $€$ якісно відмінною від концепції «об'єкт злочину - суспільні відносини», очевидно, завідомо приречені на невдачу.

\section{Jimepamypa}

1. Фесенко Є.В. Об'єкт злочину з погляду реалій. Юридичний вісник України. 1997. № 33. С. 75-78.

2. Матишевський П.С., Фесенко Є.В. Об'єкт злочину. Кримінальне право України: Загальна частина / за ред. П.С. Матишевського, П.П. Андрушка, С.Д. Шапченка. Київ : Юрінком Інтер, 1997.506 с.

3. Фесенко Є.В. Цінності як об'єкт злочину. Право України. 1999. № 6. С. 75-78.

4. Фесенко Є.В. Злочини проти здоров'я та системи заходів з його охорони : монографія. Київ : Атіка, 2004. 377 c.

5. Матишевський П.С. Кримінальне право України: Загальна частина : підручник для студ. юрид. вузів і фак. Київ : А.С.К., 2001. 347 с.

6. Андрушко П.П., Стрижевська А.А. Загальна характеристика злочинів у сфері службової діяльності. Законодавство України: Науково-практичні коменmapi. 2005. № 9. C. 28-87.

7. Андрушко П.П., Стрижевська А.А. Злочини у сфері службової діяльності: кримінально-правова характеристика : навчальний посібник. Київ : Юрисконсульт, 2006. 342 с.

8. Коржанський М.Й. Предмет і об'єкт злочину : монографія. Д. : Юридична академія міністерства внутрішніх справ ; Ліра ЛТД, 2005. 252 с.

9. Белоконев В.Н. Чему причиняют вред преступления? Юридическая практика. 2000. № 23. С. 11-17.

10. Лихова С.Я. Злочини у сфері реалізації громадянських, політичних та соціальних прав і свобод людини і громадянина (розділ V Особливої частини КК України) : монографія. Київ : Київський університет, 2006.573 c.

11. Гавриш С.Б. Кримінально-правова охорона довкілля в Україні. Проблеми теорії, застосування і розвитку кримінального законодавства. Київ : Інститут законодавства України, 2002. 634 с. 
12. Каган М.С. Философская теория ценности. Санкт-Петербург : Петрополис, 1997. 205 с.

13. История теоретической социологии : в 4 т./ ответ. ред. и составитель Ю.Н. Давыдов. Москва : Канон + , 2002. Т. 2. $556 \mathrm{c.}$

14. Рудельсон Е.А. Неокантианское учение о ценностях (Фрейбургская школа). Проблема ценности в философии / под ред. А.Г. Харлачева. Ленинград : Наука, 1966. С. $128-143$.

15. Столович Л.Н. Природа эстетической ценности. Москва : Политиздат, $1972.271 \mathrm{c.}$

16. Дробницкий О.Г. Мир оживших предметов. Проблема ценности и марксистская философия. Москва : Издательство политической литературы, 1967. $351 \mathrm{c}$

17. Беккер Г., Босков А. Современная социологическая теория в её преемственности и изменении / пер. с англ. В.М. Корзинкина и Ю.В. Семёнова, общ. ред. Д.И. Чеснокова. Москва : Издательство иностранной литературы, 1961.895 с.

18. Соколов Э.В. Основные идеи общей теории ценностей Р.Б. Перри. Проблела иенностей в философии / под ред. А.Г. Харлачева. Ленинград : Наука, 1966. С. $155-170$.

19. Лосский Н.О. Ценность и бытие. Париж : YMCA-PRESS, 1931. $135 \mathrm{c}$

20. Василенко В.О. Цінність і оцінка. Київ : Наукова думка, 1964. 139 с.

21. Тугаринов В.П. Теория ценностей в марксизме. Ленинград : Изд-во Ленинградского университета, $1968.124 \mathrm{c.}$

22. Дробницкий О.Г. Некоторые аспекты проблемы ценностей. Проблела иенности в философии под ред. А.Г. Харлачева. Ленинград : Наука, 1966. C. $25-40$.

23. Нарский И.С. Диалектическое противоречие и логика познания. Москва : Наука, 1969. 246 с.

24. Попов М.В. Аксіологія і медицина (Проблеми цінностей і медицина). Київ : ПАРАПАН., 2003. 282 с.

25. Демидов Ю.А. Социальная ценность и оценка в уголовном праве. Москва : Юридическая литература, $1975.184 \mathrm{c}$.

26. Богомолов А.С. Опредмечивание, ценности и социологическое познание. Социологические исследования. 1975. № 2. С. 54-61.

27. Кривуля О.М. Філософія : навчальний посібник. Харків : ХНУ імені В.Н. Каразіна, 2010. 592 с.

28. Азаров Д.С. Злочини у сфері комп'ютерної інформації (кримінально-правове дослідження) : монографія. Київ : Атіка, 2007. 304 с.

\section{Анотація}

Давидович I. I., Задоя К. П. Ціннісна концепція об'єкта злочину в доктрині кримінального права України: проблеми філософського підгрунтя. - Стаття.

У статті розглянуто питання про філософські засади так званої ціннісної концепції об’єкта злочину. Ціннісна концепція об'єкта злочину постала в 1990-х роках як альтернатива звичній для радянського періоду концепції об'єкта злочину, згідно з якою об'єктом злочину є суспільні відносини. На противагу останній концепції, ціннісна концепція виходить із того, що злочин посягає не на суспільні відносини, а на певні цінності: потерпілих, їхні інтереси та права; соціальні зв’язки, предмети (матеріалізовані блага); нематеріалізовані блага, які належать потерпілим.

Ціннісна концепція об'єкта злочину критикувалася в доктрині кримінального права з різних точок зору, однак предметом критики не були філософські засади цієї концепції. Прихильники ціннісної концепції вважають, що вона грунтується на вченні про цінності, яке сформувалося в рамках діалектичного матеріалізму, так званій марксистській теорії цінностей.

Однак під час детального аналізу виявляється, що насправді ціннісна концепція об’єкта злочину в її сучасному вигляді не узгоджується як з основними постулатами діалектичного матеріалізму щодо цінностей, так і з іншими напрямами аксіологічного вчення. Проблема, зокрема, полягає в тому, що ціннісна концепція об'єкта злочину тяжіє до визнання об'єктами злочину (цінностями) певних предметів (явищ), але не в суб'єкт-об'єктних відносинах 3 приводу цих предметів (явищ).

Якби ціннісна концепція об'єкта злочину справді була б заснована на марксистській теорії цінностей, вона фактично була б іншою формою вираження концепції «об'єкт злочину - суспільні відносини» .

Ключові слова: об'єкт злочину, цінності, суспільні відносини, ціннісна концепція об'єкта злочину, діалектичний матеріалізм.

\section{Summary}

Davidovich I. I., Zadoya K.P. The value concept of a crime object in the doctrine of criminal law of Ukraine: problems of philosophical basis. - Article.

The article considers the philosophical foundations of the so-called value concept of a crime object. The value concept of a crime object emerged in the 1990s as an alternative to the common concept of a crime object in the Soviet period, according to which the object of crime is public relations. Contrary to the latter, the value concept is based on the fact that the crime affects not social relations, but certain values: the victims, their interests and rights; social connections, objects (materialized goods); non-materialized goods belonging to the victims.

The value concept of a crime object was criticized in the doctrine of criminal law from different points of view, but the philosophical basis of this concept was not the object of criticism. Proponents of the value concept believe that it is based on the doctrine of values, which was formed within the framework of dialectical materialism, the so-called Marxist theory of values.

However, a detailed analysis reveals that in reality the value concept of a crime object in its modern form is inconsistent with the basic tenets of dialectical materialism about values, and with other directions of axiological teaching. The problem, in particular, is that the value concept of a crime object tends to recognize certain objects (phenomena) as crime objects (values), but not roots in the subject-object relations based on these objects (phenomena).

Moreover, if the value concept of a crime object were indeed based on a Marxist theory of values, it would in fact be another form of expression of the concept that "a crime object is social relations".

Key words: crime object, values, social relations, value concept of a crime object, dialectical materialism. 